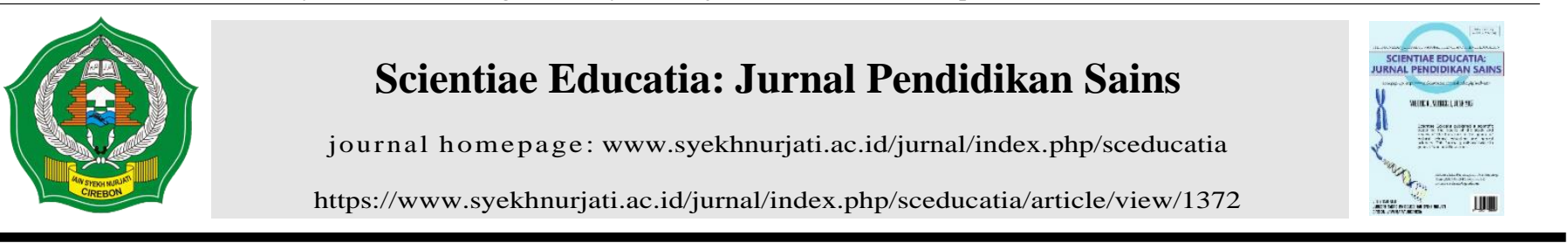

\title{
Efektivitas Pembelajaran Kapita Selekta Biologi Berbasis Masalah Untuk Membentuk Habits Of Mind Mahasiswa Calon Guru
}

\author{
Ria Yulia Gloria \\ Jurusan Tadris IPA Biologi, IAIN Syekh Nurjati Cirebon, Jawa Barat, 45132, Indonesia
}

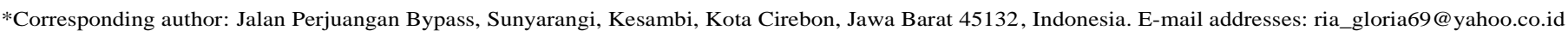

\section{a r t i c 1 e i n f o}

Article history:

Received 24 February 2017

Received in revised form $24 \mathrm{Mei}$

2017

Accepted 9 June 2017

Available online June 2017

Keywords:

Habits of Mind

Problems Based Learning

Capita Selecta Biology

Kata Kunci:

Habits of Mind

Pembelajaran Berbasis Masalah

Kapita Selekta Biologi

\section{a b s t r a c t}

This study aims to explore the effectiveness in learning Capita Selecta of Biology based on the problem to create a Habits of Mind. This research carried out by the background wants to improve the quality of thinking, one of which is the ability of individuals to behave intelligently, or called Habits of Mind. Hence the need for a study that provides the space and the opportunity for students to build a real knowledge through the concrete experiences, or learning which is constructivism (Dahar, 2001; Olson, 2009). The examples of such learning are learning based on problems. To implement the required courses that have complex concepts one of which is the course of Capita Selecta Biology. Capita Selecta Biology includes one of the subjects that studying various biological topic complete and comprehensive. The concepts in the course of Capita Selecta Biology requires high-level thinking skills because there are many abstract concepts and need a strong imagination. The study aims to seek the learning effectiveness of Capita Selecta Biology based on the problems which create a Habits of Mind. The method of this research is a quantitative pre-experimental design that uses one group pretest-posttest design. After doing the research, it can be concluded that the learning Capita Selecta Biology based on the problems was effective in forming the Habits of Mind of students as teachers candidate, in particular, the effective toward the formation of critical thinking indicators of Habits of Mind. The response of students to studied Capita Selecta Biology based on the problems included in the strong criteria. This shows that the learning Capita Selecta Biology based on the problems can be received positively by students.

Penelitian ini bertujuan untuk mencari efektivitas pembelajaran Kapita Selekta Biologi berbasis masalah terhadap pembentukan Habits of Mind. Penelitian dilakukan dengan latar belakang ingin meningkatkan kualitas berpikir, salah satunya adalah kemampuan individu untuk berperilaku cerdas, atau disebut Habits of Mind. Oleh karena itu perlu suatu pembelajaran yang memberikan ruang dan kesempatan kepada mahasiswa untuk membangun pengetahuannya secara nyata melalui pengalaman konkrit, atau pembelajaran yang bersifat konstuktivisme (Dahar, 2011; Olson, 2009). Contoh pembelajaran seperti itu adalah pembelajaran yang berbasis masalah. Untuk mengimplementasikannya dibutuhkan mata kuliah yang memiliki konsep yang kompleks salah satunya adalah mata kuliah Kapita Selekta Biologi. Kapita Selekta Biologi termasuk salah satu mata kuliah yang mempelajari berbagai topik biologi yang lengkap dan komprehensif. Konsep-konsep pada mata kuliah Kapita Selekta Biologi memerlukan kemampuan berfikir tingkat tinggi karena banyak terdapat konsep-konsep yang abstrak dan perlu daya imajinasi yang kuat. Maka penelitian ini bertujuan untuk mencari efektivitas pembelajaran Kapita Selekta Biologi berbasis masalah terhadap pembentukan Habits of Mind. Metode yang digunakan adalah kuantitatif pre-experimental design yang menggunakan one-group Pretest-postest Design. Instrumen penelitian yang digunakan adalah angket penelusuran habits of mind yang memuat kategori habits of mind menu rut Marzano dan angket respon mahasiswa terhadap pembelajaran berbasis masalah. Berdasarkan uji-t dapat disimpulkan bahwa Pembelajaran Kapita Selekta Biologi berbasis masalah efektif dalam membentuk Habits of Mind mahasiswa calon guru, terutama efektif terhadap pembentukan indikator critical thinking dari Habits of Mind. Respon mahasiswa terhadap pembelajaran Kapita Selekta Biologi berbasis masalah termasuk kedalam kriteria kuat. Hal ini menujukkan bahwa pembelajaran Kapita Selekta Biologi berbasis masalah dapat diterima secara positif oleh mahasiswa.

2017 Scientiae Educatia: Jurnal Pendidikan Sains

\section{Pendahuluan}

Hasil dari suatu pembelajaran adalah berubahnya perilaku dan keterampilan berpikir menjadi semakin baik. Diantara tujuan pendidikan yang harus dicapai adalah mengembangkan kebiasaan mental individu dan memahami segala yang berkaitan dengan hidupnya atau kemampuan individu untuk berperilaku cerdas, hal ini disebut Habits of Mind (Costa \& Kallick, 2000). Untuk dapat memperoleh kemampuan berpikir cerdas perlu ada upaya yang sesuai, salah satunya adalah dengan memperbaiki proses pembelajaran.

Praktik pembelajaran yang dilakukan pada umumnya masih mengutamakan dan berorientasi kepada penguasaan materi dan nilai hasil belajar. Dari hasil pengamatan yang dilakukan sebelum penelitian, ditemukan bahwa tujuan pendidikan 
difokuskan berupa mahasiswa harus menguasai informasi yang terkandung pada materi pelajaran. Siswa akan dinyatakan berhasil berdasarkan ukuran berapa banyak materi yang sudah dikuasai. Kegunaan materi yang dia kuasai untuk kehidupannya sehari-hari, bagaimana keterkaitan antara yang dipahami dengan perilaku mereka dalam kehidupan belum diperhatikan. Hal ini tidak sejalan dengan hakikat dari tujuan pendidikan yaitu ingin membentuk manusia seutuhnya. Manusia seutuhnya berarti memiliki kemampuan intelektual, sikap dan juga keterampilan yang diharapkan. Jadi hakikat sebenarnya dari tujuan pendidikan adalah mengembangkan kebiasaan mental yang menjadikan individu siap belajar berbagai hal yang mereka butuhkan dalam kehidupannya. Setiap individu dalam kehidupannya akan berhadapan dengan berbagai masalah, maka keterampilan bagaimana mereka menghadapi permasalahan tersebut perlu dimiliki, dalam situasi seperti itu setiap individu memerlukan perilaku cerdas untuk mengatasinya (Habits of Mind).

Memiliki Habits of Mind berarti memiliki watak dan prilaku yang cerdas di saat menghadapi masalah (Costa dan Kallick, 2000 dan Carter, et al, 2005). Hal ini menjelaskan bahwa tujuan dari suatu pembelajaran bukan hanya membuat mahasiswa menjadi mengerti dan memahami suatu konsep, namun mereka juga harus memiliki perilaku yang cerdas di saat mereka dihadapkan dalam suatu masalah yang belum diketahuinya. Untuk mendapatkan kemampuan dan karakter berperilaku cerdas siswa ataupun mahasiswa maka kita perlu melakukan berbagai upaya pembelajaran yang dapat melatih siswa ataupun mahasiswa mendapatkan keterampilan tersebut. Salah satu pembelajaran yang dapat melatih terbentuknya Habits of Mind adalah pembelajaran berbasis masalah. Pembelajaran berbasis masalah dapat melatih Habits of Mind karena karakteristik dari pembelajaran berbasis masalah berkaitan dengan karakteristik Habits of Mind. Misalnya adakah tanda seseorang memiliki kemampuan berpikir cerdas adalah dapat memecahkan masalah, dan membuat kesimpulan dari hasil memikirkan masalah tersebut.

Pembelajaran yang baik untuk siswa ataupun mahasiswa adalah suatu pembelajaran yang memberikan ruang dan kesempatan kepada mereka untuk membangun pengetahuannya secara nyata melalui pengalaman konkrit. Pembelajaran yang seperti itu dikenal dengan pembelajaran yang bersifat konstruktivisme. Pembelajaran yang bersifat kontruktivisme dapat melatih siswanya untuk membangun pengetahuannya sendiri, salah satunya adalah pembelajaran yang memberikan sejumlah masalah yang harus dipecahkan oleh siswa. PBL (pembelajaran berbasis masalah) adalah suatu model pembelajaran yang menguguhkan suatu pembelajaran yang memberikan suatu masalah dan problematik yang harus dipecahkan oleh siswa. Pada pembelajaran yang berbasis masalah di dalamnya akan membuat siswa bergerak menuju suatu investigasi dan penyelidikan. Menurut Arends (2008), esensi pembelajaran berbasis masalah adalah menyuguhkan berbagai situasi bermasalah yang autentik dan bermakna kepada siswa. Dengan diberikan suatu masalah diharapkan siswa akan berusaha dengan berbagai cara berpikir untuk mencari solusi agar masalah tersebut dapat dipecahkan. Esensi dari pembelajaran berbasis masalah ini erat kaitannya dengan komponen Habits of Mind (self regulation, critical thinking, dan creative thinking), sehingga pembelajaran berbasis masalah dapat menumbuhkan Habits of Mind dari siswa/mahasiswa.

Berbagai penelitian telah membuktikan bahwa Habits of Mind dapat dilatih, dikembangkan dan dibentuk (Sriyati, 2010; Sriyati, 2011; Anwar, 2005; Cheung dan Hew, 2008). Penelitian-penelitian tersebut mengungkapkan berbagai strategi dan pendekatan dalam pembelajaran yang dapat dilakukan untuk mengembangkan dan melatih Habits of Mind. Namun belum ada pembelajaran berbasis masalah yang dikaitkan dengan Habits of Mind, maka perlu adanya penelitian yang mengkaitkan pembelajaran berbasis masalah dengan terbentuknya Habits of Mind pada mahasiswa.

Kapita Selekta Biologi adalah mata kuliah yang mengkaji materi/konsep Biologi di SMA. Secara umum materi Biologi merupakan konsep yang perlu pemahaman mendalam, dan beberapa konsepnya termasuk kedalam kategori sulit dipahami karena berkaitan dengan mikroskopis dan fisiologi, sehingga banyak sekali ditemukan konsep-konsep yang bersifat abstrak. Oleh karena itu sangat diperlukan pembelajaran yang mampu menggali pemahaman siswa dan pembelajaran yang merangsang keterampilan berpikir siswa baik keterampilan berpikir kritis maupun berpikir kreatif. Sesuai dengan karakteristik pembelajaran berbasis masalah maka pembelajaran ini dapat menjadi alternatif dalam memecahkan kesulitan belajar siswa khususnya pada mata kuliah Kapita Selekta Biologi.

Berdasarkan uraian diatas maka perlu adanya penelitian mengenai pembelajaran berbasis masalah yang diterapkan pada mata kuliah Kapita Selekta Biologi untuk menumbuhkan Habits of Mind mahasiswa calon guru Biologi.

\section{Metode Penelitian}

Populasi dan Sampel. Penelitian dilakukan pada pada bulan April sampai dengan bulan Juli 2016. Subjek dalam penelitian ini adalah mahasiswa calon guru Biologi yang mengikuti mata kuliah Kapita selekta Biologi, di IAIN Syekh Nurjati Cirebon. Populasi dari penelitian ini adalah seluruh mahasiswa calon guru Biologi yang mengikuti mata kuliah Kapita Selekta Biologi, dan sampel dari penelitian adalah mahasiswa calon guru Biologi kelas A semester 6.

Desain Penelitian. Penelitian ini menggunakan metode kuantitatif pre-experimental design yang menggunakan oneGroup Pretest-Postest Design (Creswell, 2014 ; Creswell, 2015).

Tabel 1. Desain Penelitian

\begin{tabular}{lll}
\hline \multicolumn{1}{c}{ Pretes } & Perlakukan & Postes \\
\hline $\mathrm{O} 1$ & $\mathrm{O}$ \\
\hline Ket : & \\
$\mathrm{O}=$ tes untuk mengukur Habits of Mind mahasiswa \\
$\mathrm{X} 1=$ Pembelajaran Kapita Selekta Biologi berbasis masalah
\end{tabular}


Analisis Data Respon Mahasiswa Terhadap Pembelajaran Kapita Selekta Biologi Berbasis Masalah. Respon mahasiswa terhadap pembelajaran Kapita Selekta Biologi berbasis masalah untuk membentuk habits of mind dihitung presentasinya dari setiap indikator. Angket respon mahasiswa terdiri dari 18 item yang terdiri dari 6 pernyataan negatif dan 12 pernyataan positif.

Hasil dari angket respon akan dianalisis secara deskriftif kualitatif. Data angket yang berupa skala likert terdiri dari lima option yaitu SS (sangat setuju), S (setuju), R (ragu-ragu), TS (tidak setuju), dan STS (sangat tidak setuju). Pernyataan angket positif dinilai secara berurutan yaitu $5,4,3,2$, 1 . Sedangkan untuk pernyataa angket negatif dinilai secara berurutan $1,2,3,4$, 5 .

Untuk menghitung persentase dari setiap variabel digunakan rumus :

$$
\mathrm{P}=\frac{S}{N} \times 100 \%
$$

Keterangan :

$\mathrm{P}=$ persentase sub variabel

$\mathrm{S}=$ jumlah skor tiap sub variabel

$\mathrm{N}=$ jumlah skor maksimum

Hasil angket akan diinterpretasikan sebagai berikut :

$0 \%-20 \%=$ sangat lemah

$21 \%-40 \%=$ lemah

$41 \%-60 \%=$ cukup

$61 \%-80 \%=$ kuat

$81 \%-100 \%=$ sangat kuat

(Riduwan , 2010)

Analisis Data Angket Penelusuran Habits of Mind. Analisis data untuk angket penelusuran habits of mind yang terdiri dari 15 pernyataan yang terdiri dari tiga kategori menurut Marzano (1993), yaitu : self regulation, critical thinking, dan creative thinking.

Peningkatan habits of mind mahasiswa dihitung berdasarkan nilai N-gain. Rubrik menetapkan nilai tertinggi 4 dan terendah 1. Kriteria N-Gain yang digunakan adalah menurut Meltzer (2002) yaitu :

Tabel 2. Kriteria N-Gain

\begin{tabular}{ll}
\hline Gain Ternormalisasi & N-Gain \\
\hline Rendah & $0-0,30$ \\
Sedang & $0,31-0,69$ \\
Tinggi & $0,70-1,00$ \\
\hline
\end{tabular}

\section{Hasil dan Pembahasan}

Hasil penelitian yang berupa data-data yang diperoleh kemudian akan dipaparkan berdasarkan urutan pertanyaan penelitian. Pada penelitian ini ada dua pertanyaan penelitian yang akan dipaparkan hasilnya, yaitu (1) apakah pembelajaran Kapita Selekta Biologi berbasis masalah efektif dalam membentuk Habits of Mind mahasiswa calon guru Biologi?, dan (2) bagaimana respon siswa pada Pembelajaran Kapita selekta Biologi berbasis masalah? Kedua pertanyaan penelitian akan dijawab berdasarkan hasil penelitian yang diuraikan berikut. Hasil diperoleh setelah melakukan analisis data. Pembahasan terdiri dari pembahasan efektivitas pembelajaran Kapita selekta berbasis masalah terhadap terbentuknya Habits of mind, dan pembahasan mengenai respon mahasiswa terhadap pembelajaran Kapita Selekta berbasis masalah.

\section{Efektivitas Pembelajaran Kapita Selekta Berbasis Masalah terhadap Pembelntukan Habits of Mind Mahasiswa}

Efektivitas pembelajaran Kapita Selekta berbasis Masalah terhadap terbentuknya Habits of Mind diketahui berdasarkan data dari angket penelusuran Habits of Mind. Angket ini diberikan sebelum dan sesudah pembelajaran Kapita Selekta Biologi Berbasis Masalah.

Dari rata-rata N-Gain yang diperoleh, terdapat hasil yang berbeda antara nilai Habits of Mind sebelum penerapan pembelajaran Kapita selekta berbasis masalah dan sesudah penerapan, meskipun nilai N-Gain tergolong kedalam kriteria rendah. Dari semua mahasiswa yang diteliti peningkatan Habits of Mind nya, terdapat 3 mahasiswa yang memiliki N-Gain dengan kriteria sedang atau sekitar $9 \%$. Sebanyak $54 \%$ memiliki peningkatan Habits of Mind yang rendah, dan sisanya tidak mengalami peningkatan sama sekali $(\mathrm{N}-$ Gain $=0)$.

Untuk dapat melihat lebih jelas bagaimana perbedaan nilai Habits of Mind mahasiswa sebelum dan sesudah mereka diberi perlakuan, digambarkan dalam diagram batang pada gambar 1. 


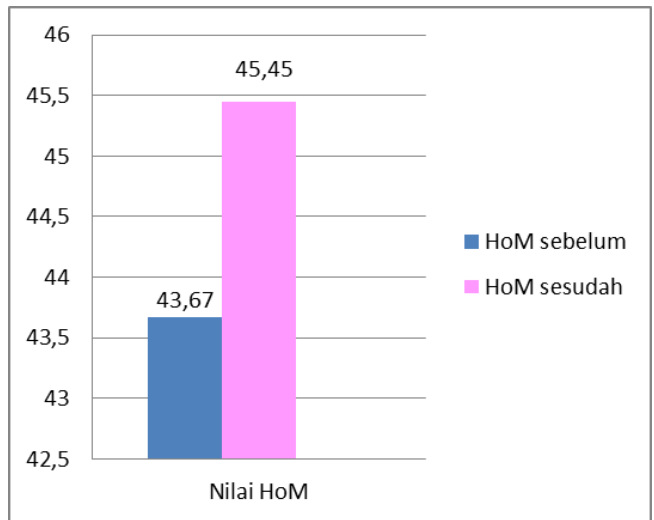

Gambar 1. Perbandingan Nilai Habits of Mind sebelum dan sesudah pembelajaran Kapita Selekta Biologi berbasis masalah

Gambar 1. menampilkan grafik mengenai nilai Habits of Mind mahasiswa sebelum dan sesudah mendapat pembelajaran Kapita Selekta Biologi berbasis masalah. Nilai Habits of Mind mahasiswa setelah mendapat pembelajaran Kapita Selekta Biologi meningkat sebesar 2,69\%. Peningkatan sebesar 2, $69 \%$ adalah peningkatan Habits of Mind tanpa melihat kriteria per indikator. Peningkatan per indikator Habits of Mind yang terdiri dari self regulation, critical thinking, dan creative thinking dapat dilihat pada Gambar 2.

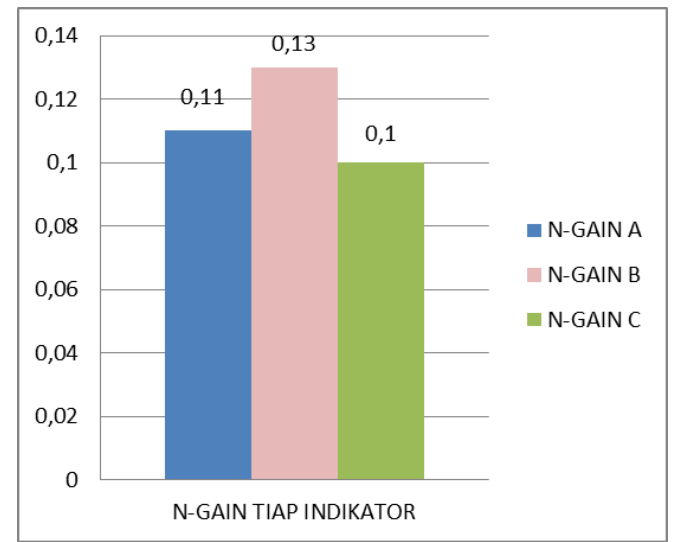

Ket: $\mathrm{A}=$ self regulation, $\mathrm{B}=$ critical thinking, $\mathrm{C}=$ creative thinking

Gambar 2. Perbandingan Peningkatan (N-Gain) antar indikator habits of mind

Pada gambar 2. terlihat perbandingan N-Gain antara tiga indikator Habits of Mind yang terdiri dari self regulation, critical thinking, dan creative thinking. Dari ketiga indikator, indikator critical thinking adalah yang paling besar nilai N-Gainnya, dan indikator creative thinking adalah yang paling kecil nilai N-Gainnya. Meskipun demikian selisih ketiganya tidak terlalu besar, yaitu dari yang tertinggi ke yang kedua tertinggi hanya memiliki selisih 0,02, dan selisih yang kedua dengan yang terendah hanya 0,01.Dari analisis data yang telah dilakukan, diperoleh bahwa nilai Habits of Mind di awal pembelajaran berbeda signifikan berdasarkan uji t-paired test dibandingkan dengan nilai Habits of Mind setelah pembelajaran Kapita Selekta Biologi berbasis masalah.

Berdasarkan hasil analisis secara statistik, dapat disimpulkan bahwa Pembelajaran Kapita Selekta Berbasis Masalah efektif dapat meningkatkan Habits of Mind mahasiswa. Hal ini berkaitan dengan karakter dari pembelajaran berbasis masalah dari Lang dan Evan (2006), Pembelajaran berbasis masalah merupakan pembelajaran yang dapat meningkatkan keterampilan berpikir hal itu dikarenakan mahasiswa akan berusaha memecahkan permasalahan yang dihadapinya. Sesuai dengan karakteristik dari pembelajaran berbasis masalah yaitu 1) berpusat pada siswa, 2) pembelajaran terjadi dalam kelompok kecil, 3) pendidik sebagai fasilitator dan pembimbing, 4) permasalahan merangsang pembelajaran, 5) permasalahan sebagai sarana pengembangan memecahkan masalah, 6) informasi baru diperoleh melalui pembelajaran sendiri.

Karakter dari pembelajaran berbasis masalah ternyata berkaitan erat dengan indikator dari Habits of Mind. Karakter pembelajaran yang berpusat pada siswa dan pembelajaran kelompok berkaitan dengan penumbuhan indikator Habits of Mind yang berupa self regulation. Karakter pembelajaran berbasis masalah yang berupa permasalahan yang merangsang pembelajaran dan karakter mendapat informasi baru yang diperoleh sendiri berkaitan dengan Habits of Mind indikator critical thinking. Karakter pembelajaran berbasis masalah permasalahan sebagai sarana pengembangan keterampilan memecahkan masalah berkaitan erat dengan Habits of Mind indikator creative thinking. 
Habits of Mind memiliki tiga indikator yaitu self regulation, critical thinking dan creative thinking. Pembelajaran berbasis masalah yang diterapkan pada perkuliahan Kapita Selekta Biologi ternyata memiliki nilai berbeda dari setiap indikator Habits of Mind, hal ini dapat dilihat dari hasil Gambar 2. dari nilai N-gain yang diperoleh ternyata nilai N-Gain terbesar diperoleh pada indikator Habits of Mind yaitu critical thinking. Duch (2001), berpendapat bahwa pembelajaran berbasis masalah akan menyiapkan siswa untuk berpikir lebih kritis dan analitis. Sementara itu nilai N-Gain terkecil diperoleh pada indikator creative thinking. Hal ini karena saat pembelajaran berbasis masalah mahasiswa lebih terdorong untuk bagaimana mereka dapat memecahkan masalah-masalah yang terdapat pada soal yang diberikan dosen. Soal-soal yang berbasis masalah yang diberikan kepada mahasiswa merupakan soal yang membutuhkan keterampilan berpikir kritis dari mahasiswa, sehingga mereka dapat menemukan jawabannya. Selain itu pembelajaran berbasis masalah membuat keterampilan berpikir kritis mahasiswa semakin kuat karena terdapat kegiatan diskusi dimana mahasiswa berperan aktif dalam mengkritisi hasil diskusi. Kegiatan tersebut mendorong terbentuknya Habits of Mind mahasiswa, terutama keterampilan berpikir kritis mereka (critical thinking).

Self regulation adalah indikator yang kedua dari Habits of Mind yang juga terbentuk dalam pembelajaran Kapita Selekta berbasis masalah. hal ini terjadi karena salah satu karakter dari pembelajaran berbasis masalah adalah berpusat pada siswa, dengan demikian mahasiswa akan terdorong untuk lebih kritis terhadap kemampuannya sendiri.

Indikator Habits of Mind berupa creative thinking meskipun merupakan indikator yang memliki N-gain terendah namun pada dasarnya tetap mengalami peningkatan dari sebelum pembelajaran ke setelah menerima pembelajaran. Keterampilan berpikir kreatif tetap terbentuk dalam pembelajaran berbasis masalah hal ini erat kaitannya dengan karakter pembelajaran berbasis masalah yaitu terdapat pengembangan keterampilan memecahkan masalah dan mendapatkan solusi.

Dari hasil penelitian dan pembahasan maka dapat disimpulkan bahwa pembelajaran Kapita Selekta Berbasis masalah efektif terhadap pembentukan Habits of Mind. Hal ini membuktikan bahwa karakter pembelajaran berbasis masalah berkaitan dengan kemampuan berpikir cerdas baik itu kemampuan menilai diri sendiri, kemampuan berpikir kritis, dan kemampuan berpikir kreatif.

Pengaruh positif pembelajaran berbasis masalah juga ditemukan dalam penelitian-penelitian lainnya yang relevan. Hasil penelitian penelitian mengenai pembelajaran berbasis masalah menyimpulkan bahwa pembelajaran berbasis masalah Penerapan model pembelajaran aktif berpengaruh positif terhadap prestasi akademik dan sikap terhadap pembelajaran sains. Aplikasi pembelajaran berbasis masalah berpengaruh positif terhadap pengembangan konseptual dan mengurangi miskonsepsi pada siswa (Akinoglu, O. And Tandagon, O., 2007). Pembelajaran berbasis masalah dapat meningkatkan kemampuan Generik Sains (Susanti, 2011). Skor prestasi akademik dan keterampilan kinerja yang diperoleh melalui pembelajaran berbasis masalah lebih tinggi dibandingkan dengan pembelajaran sacara tradisional (Araz, G. And Sungur, S., 2007). Permasalahan “ill structure" dalam konteks pembelajaran berbasis masalah mempengaruhi cara siswa bekerja melalui permasalahan mereka dalam kerja proyek. Dimana pembelajaran berbasis masalah dapat melibatkan mahasiswa dalam memperoleh proses kognitif (merumuskan permasalahan, mengajukan pertanyaan, membuat perbandingan, menerapkan pengetahuan awal ke dalam situasi baru, dan juag membuat keputusan (Chin, C. And Chia. L.G., 2005). Pembelajaran berbasis masalah merupakan cara yang lebih efektif dalam merangsang pembelajaran aktif yang berpusat pada siswa (Chin, C. And Chia. L.G., 2004). Pembelajaran berbasis masalah sangat berguna dalam memahami fisiologi. 60\% lebih dari mahasiswa menyatakan pembelajaran bebasis masalah dapat pertukaran ide dan pendapat terjadi lebih baik, sehingga dapat lebih mudah menyelesaikan ujian akhir (Glosh, S. And dawka, V., 2000).

\section{Respon Mahasiswa terhadap Pembelajaran Kapita Selekta Berbasis Masalah dalam Membentuk habits of Mind Mahasiswa.}

Dampak dari pembelajaran Kapita Selekta Biologi berbasis masalah, dapat dilihat dari respon yang diberikan mahasiswa terhadap pembelajaran tersebut. Respon tersebut berupa tanggapan mahasiswa setelah pembelajaran berlangsung. Kuesioner yang digunakan untuk menjaring tanggapan mahasiswa ini berupa kuesioner dengan 18 pernyataan. Untuk setiap pernyataan positif maka setiap pernyataan diberi bobot $5=$ sangat setuju, $4=$ setuju, $3=$ ragu-ragu, $2=$ tidak setuju, dan $1=$ sangat tidak setuju. Untuk pernyataan negatif maka penilaiannya adalah dibalik.

Berdasarkan data respon mahasiswa untuk pernyataan positif, sebanyak 7,7 \% menjawab sangat setuju, 54,2 \% menjawab setuju, 4,7 \% menjawab ragu-ragu, 0,6\% menjawab tidak setuju, dan tidak ada yang menjawab sangat tidak setuju. Sedangka untuk pernyataan yang bersifat negatif, sebanyak 0,6 \% menjawab sangat setuju, sebanyak 10,4\% menjawab setuju, sebanyak 9,5\% menjawab ragu-ragu, 11,27\% menjawab tidak setuju, dan 1,17\% menjawab sangat tidak setuju.

Respon mahasiswa terhadap pernyataan positif seluruhnya masuk dalam kriteria kuat. Respon mahasiswa terhadap pernyataan negatif terdapat 45,45 \% memiliki kriteria kuat dan 54,54\% memiliki kriteria lemah.

Respon mahasiwa terhadap pernyataan negatif terdapat dua kriteria, yaitu kuat dan lemah. Respon mahasiswa dengan kriteria kuat lebih dominan dibandingkan respon mahasiswa dengan kriteria lemah. Hasil penelitian menunjukkan bahwa respon mahasiswa terhadap pembelajaran Kapita Selekta Berbasis masalah diterima baik oleh mahasiswa. Kesimpulan itu didapatkan dari hasil jawaban respon mahasiswa terhadap pernyataan positif dan juga dari jawaban mahasiswa mengenai pernyataan negatif.

Jawaban sangat setuju dan setuju paling banyak diberikan oleh mahasiswa yaitu pada pernyataan nomor 1, 2, dan 3. Semua pernyataan yang paling banyak dijawab setuju dan sangat setuju adalah pernyataan dengan sifat positif. Pernyataan yang paling 
banyak dijawab sangat tidak setuju dan tidak setuju adalah nomor 10, nomor tersebut adalah pernyataan yang memiliki sifat negatif.

Berdasarkan data respon mahasiswa terlihat untuk pernyataan positif, mahasiswa menerima dan merespon baik terhadap pembelajaran Kapita Selekta berbasis masalah, dengan kriteria respon mahasiswa adalah kuat. Sedangkan untuk pernyataan yang bersifat negatif. Hanya sedikit saja mahasiswa yang memberi respon negatif terhadap pembelajaran Kapita Selekta Biologi berbasis masalah, atau hanya sedikit saja mahasiswa yang tidak suka dengan penerapan pembelajaran tersebut. Respon mahasiswa dengan pernyataan negatif termasuk kedalam kriteria lemah.

Respon mahasiswa terhadap pembelajaran Kapita Selekta berbasis masalah sejalan dengan peningkatan nilai Habits of Mind mahasiswa. Peningkatan Habits of Mind mahasiswa dapat disimpulkan terjadi karena pembelajaran tersebut diterima dengan baik oleh mahasiswa. Pembelajaran Kapita Selekta Biologi berbasis masalah telah merubah karakter mahasiswa kearah yang lebih baik, artinya tujuan pembelajaran sudah dapat dikatakan berhasil. Hal ini sesuai dengan pendapat Costa \& Kallick (2000), hasil dari suatu pembelajaran adalah berubahnya perilaku dan keterampilan berpikir menjadi semakin baik. Diantara tujuan pendidikan yang harus dicapai adalah mengembangkan kebiasaan mental individu dan memahami segala yang berkaitan dengan hidupnya atau kemampuan individu untuk berperilaku cerdas, hal ini disebut Habits of Mind .

\section{Simpulan}

Dari hasil penelitian berupa peningkatan nilai Habits of Mind dan respon mahasiswa, dapat terlihat kaitan dan hubungan antara Habits of Mind dengan pembelajaran Kapita Selekta Biologi berbasis masalah. Banyaknya mahasiswa yang memberi respon terhadap pembelajaran yang digunakan membuat meningkatnya pula kemampuan berpikir cerdas mereka (Habits of Mind). Dengan demikian dianggap sangat cocok pembelajaran Kapita Selekta Biologi berbasis masalah dalam meningkatkan Habits of Mind mahasiswa calon guru Biologi.

\section{Ucapan Terima Kasih}

Terimakasih kepada seluruh mahasiswa yang menjadi subjek dalam penelitian ini dan asisten peneliti yaitu Reri, Yanti, Idrus Hariri yang membantu untuk menganalisis data hasil penelitian.

\section{Daftar Pustaka}

Akinoglu, O, and Tandogan, R.O. (2007). "The Effect of Problem-Based Active Learning In Science Education On Students Academic Achievement, Attitude and Concept Learning". Eurasia Journal Of Matematics, Science and Technology Education. 3,(1),71-81.

Anwar, C. (2005). Penerapan Penilaian Kinerja (Performance Assessment) dalam membentuk Habits of mind Siswa Pada Pembelajaran Konsep Lingkungan. Sekolah Pasca Sarjana Pendidikan IPA UPI. Thesis; Tidak diterbitkan.

Araz, G, and Sungur, S. (2007). "Effectivenes of Problem-Based Learning On Academic Performance In Genetics". The International Union Of Biochemistry and Molecular Biologi. 35,(6),448-451.

Arends, Richard I. (2008). Learning to Teach. Yogyakarta : Pustaka Pelajar

Carter, C., Bishop, J. \& Kravits, S.L. (2005). Keys to Effective Learning Developing Powerful Habits of mind . Australia; Pearson Prentice Hall.

Cheung \& Hew, (2008). Examining Facilitators Habits of Mind and Leaners Participation. Melbourne : Proceedings Ascilite Melbourne. (Online) Tersedia : http://portal.acm.org/citation.cfm?id=1383846. (maret, 2016)

Chin, C. And Chia, L-G. (2004). "Implementing Project Work In Biology Through Problem-Based Learning". Jurnal Of Biological Education. 38,(2),69-75.

(2005). "Problem Based-Learning : Using III Structured Problems In Biology Project Work". Science Education. 90,44-67.

Creswell, J. W. (2014). Research Design, Pendekatan Kualitatif, Kuantitatif, dan Mixed. Diterjemahkan oleh: Achmad Fawaid. Yogyakarta: Pustaka Pelajar.

(2015). Riset Pendidikan : Perencanaan Pelaksanaan dan Evaluasi Riset Kualitatif dan Kuantitatif. Diterjemahkan oleh: Helly Prajitno Soecjipto. Yogyakarta : Pustaka Pelajar

Costa, A.L. \& Kallick, B. (2000). Describing 16 Habits of Mind. Habits of Mind : A Developmental Series. Alexandria, VA. (online). Tersedia: http://www.ccsnh.edu/documents/CCSNH MLC. Habits og Mind Costa Kallick.

Dahar, R. W. (2011). Teori-teori Belajar dan Pembelajaran. Jakarta: Erlangga.

Duch, B.J., Groh, S.E., and Allen, D.E. (2001). The Power of Prpblem-Based Learning. Virginia: Stylus Publishing, LCC.

Glosh, S., and Dawka, V. (2000). “Combination Of Didactic Lecture With Problem-Based Learning Sessions in Physiology Teaching in A Developing Medical College in Nepal”. Advances in Physiology Education. 24,8-12.

Lang, H.R. dan Evans, D,N. (2006). "Model, Strategies, and Methods For Effective Teaching. 1 st edition New York : Pearson Educatin, Inc.

Marzano, Pickering and McTighe. (1993). Assessing Student Outcomes Performance Assessment Using the Dimension of Learning Model. Alexandria, Virginia; Association for Supervision and Curriculum Development. 
Meltzer, D.E. (2002). The Relationship between Mathematics preparation and Conceptual Learning Gain in Pgysi cs: a Possible hidden variable in diagnostic pretest score. Am. J.Phys. 70(2). 1259-1267.Tersedia: http:/www.physics.Iastate.edu/per/does/Addendum_on_normalizedgain.pdf.

Olson, B. H. (2009). Theories of learning (Teori Belajar). Jakarta: Kencan Prenada Media Group.

Riduwan. (2010). Dasar-dasar Statistika. Bandung : Alfabeta

Schunk, Dale H. (2012). Teori-teori Pembelajaran: Perspektif Pendidikan. Yogyakarta : Pustaka Pelajar

Sriyati, dkk (2010). Kontribusi Asesmen Formatif terhadap Habits of Mind Mahasiswa Biologi. Jurnal Pengajaran MIPA, Volume 15, Nomor 2, hal 77-86.

Sriyati, Siti. (2005). Peran Asesmen Formatif dalam Membentuk Habits of Mind Mahasiswa Biologi. Sekolah Pasca Sarjana Pendidikan IPA UPI. Disertasi; Tidak diterbitkan.

Susanti, Rahmi. (2011). "Pengembangan program pembelajaran Fisiologi Tumbuhan Berbasis Masalah untuk Meningkatkan Kemampuan Generik Sains Calon Guru Biologi”. Sekolah Pasca Sarjana Pendidikan IPA UPI. Disertasi; Tidak diterbitkan. 